\title{
Problems and Measures of Innovation and Entrepreneurship Education in Chinese Colleges and Universities
}

\author{
Li Dong \\ Xi'an Aeronautical Polytechnic Institute, Xi'an, Shaanxi, China, 710089
}

Keywords: Chinese colleges and universities; innovation and entrepreneurship; measures

\begin{abstract}
With the rapid growth of China's national economy, the social environment and education environment have also been gradually improved. With the change of social needs, the mode of talent cultivation in colleges and universities has changed, gradually adapting to social needs. At present, China strongly advocates innovation and entrepreneurship of college students, and has issued a series of policies to support and encourage college students to start their own businesses. Colleges and universities, in response to the government call and the demand of social innovation business, gradually carry out creative education and establish college students' innovative undertaking business incubators. In order to improve the skills of students in higher institutions and establish a reasonable talent training structure, this paper expounds the existing problems of education in Chinese colleges and universities, solves these problems, and sets up a new education model to adapt to China's development and contribute to the rational development of the national economy.
\end{abstract}

\section{Introduction}

With the rapid growth of China's national economy, the social environment and education environment have also been gradually improved, and the social demands for talents have become more diversified. With the change of social needs, the mode of the university's talent cultivation adapts to the social needs. With the change of college students' employment and career choice, more and more college students are self-employed, and colleges and universities have become the first station to strengthen the education. Universities carry out education system of school from several aspects, such as Construction of teaching staff, students' employment idea, creation of entrepreneurial base, etc. This paper expounds the existing problems of education in Chinese universities. To solve these problems, we set up a new education model to adapt to China's development and contribute to the rational development of the national economy.

\section{The Main Problems of Innovation and Entrepreneurship Education in Chinese Colleges and Universities}

\subsection{The backward innovation and entrepreneurship education concept}

China's colleges and universities to carry out the creative education time is shorter compared with western developed countries, and its cultivation system is not fully established, which leading to most of the students is not a clear concept of innovation. At present, the reasons why innovation and entrepreneurship education is lagging behind are mainly in these aspects. Firstly, although colleges and universities choose excellent teachers for teaching through strict selection system, most of the teacher's job is too busy or limited by the nature of work, teaching stage is purely in theory. And the comprehensive quality and entrepreneurial management ability are less for starting a business. Which is difficult to improve the students' comprehensive quality ability. Second, the meaning and impact of innovation and entrepreneurship education are not in place. The students just think that education is to create a company through a good entrepreneurial project, and not understand the comprehensive abilities and qualities required for starting a business. Third, some students think that starting a business is just an activity after graduation. It's a way after we can not 
find a right job. They didn't accept the idea of starting a business in the university or just graduated.

\subsection{The weak innovation and entrepreneurship education faculty}

The innovation and entrepreneurship education of Chinese universities is only in the initial stage, so the teaching ability of teachers plays a very important role.Only a teacher with a lot of practical experience can truly lead the students to be innovative and entrepreneurial, which can cultivate students' entrepreneurial ability and consciousness.However, at present, Chinese colleges and universities are lack of resources for entrepreneurial teachers. Although teaching teachers have been trained and studied in groups, they have less experience in practice and entrepreneurship. They don't have a complete business system structure and facing the startup problem solving measures, and these abilities is not got through training and learning, which require a lot of practical experience. The single teaching method and content of colleges and universities are weak. It will lead to innovation and entrepreneurship education can not achieve the ideal goal.

\subsection{The low students' enthusiasm}

The success rate of college students' success in China is low, which is caused by many factors. In China, there are very few people who embark on the entrepreneurial path after graduation. Only about 1 percent of the students in colleges and universities start their own business after graduation, while in the United States is 30 percent. So, there is still a great gap between Chinese students and western countries. This has a great relationship with college students' enthusiasm for entrepreneurship. Which is mainly due to the lack of entrepreneurship practice in Chinese universities, and less training for innovation and entrepreneurship education. Based on the limit of entrepreneurship training in Chinese universities. Only a little student can have a chance to participate in the entrepreneurial activities organized by the university, which reduces students' enthusiasm for learning innovation and entrepreneurship.

\section{Measures for Innovation and Entrepreneurship Education in Colleges and Universities}

\subsection{Establish the goal of innovation and entrepreneurship education}

The goal of innovation and entrepreneurship education is to cultivate high-quality innovative talents, and innovative entrepreneurship teaching is a novel topic. But the education of our universities is consistent with the traditional education method, which will lead to a small gap in the final training of students. University innovation and entrepreneurship education is not the same as traditional education in the 21st century, and we must set the education target under the times development. Chinese colleges and universities must determine their own education goals, pay attention to enhance its entrepreneurial consciousness and entrepreneurial ability. Which is a great help for enhancing students' comprehensive quality and expanding students' horizon of entrepreneurship. Chinese colleges and universities must aim to identify the innovation consciousness of students, and then stimulate students' potential ability, and cultivate new highquality talents with innovative spirit.

\subsection{Strengthen the training of teachers}

The innovation and entrepreneurship education in Chinese universities is only in the initial stage, so it is necessary to improve the teachers' level and innovative thinking. The teachers can improve students' comprehensive quality ability through the teaching of innovative ideas, and enhance students' practical operation ability through the professional innovation and entrepreneurship required courses and practical activities. The teacher team which lack of innovative entrepreneurial thinking and practical experience is not in line with the innovation and entrepreneurship education target team. The team must have a lot of practical experience for supporting student all-round thinking education. And through the complete education, a practical innovation and entrepreneurship team should be developed to respond to the national call. The teachers in Chinese universities are relatively weak, and a few teachers have experienced complete professional training or have a lot of practical experience. In order to cultivate qualified new innovation and 
entrepreneurship talents, we must strengthen the training of teachers. Combining the education project with practice, the whole cultivation measures are established. School teachers participate in foreign innovation and entrepreneurship education training, enrich the teaching experience of university teachers through foreign advanced training experience, and increase the school's level of innovation and entrepreneurship education.

\subsection{Enhance college students' awareness and enthusiasm}

Innovation and entrepreneurship education is a comprehensive education. It cannot be restricted to education and practice activities in the classroom. We can increase students' awareness of innovation and entrepreneurship through abundant activities and publicity in daily life. And through questionnaire survey, group discussion and other forms to increase students' enthusiasm. Colleges and universities cultivate students' competitive awareness, innovation awareness and team awareness through professional salons, special lectures and entrepreneurship competitions, and then promoting the enthusiasm of innovation and entrepreneurship, and the social responsibility of the high school in this way. Universities should focus on innovation and entrepreneurship education to enhance students' cognition and enthusiasm, and integrate the innovation and entrepreneurship education into students' daily life.

\section{Conclusion}

China's innovation and entrepreneurship education started late, and it education still has many problems in theory and practice. China's colleges and universities should learn from the advanced innovation and entrepreneurship education experience of America, and select the suitable road to improve the innovation and entrepreneurship education. This paper expounds the existing problems of education in Chinese universities, and some Suggestions are put forward to establish the goal of innovation and entrepreneurship education, strengthen the training of teaching staff, and enhance the consciousness and enthusiasm of college students' innovation and entrepreneurship.

\section{References}

[1] Davidsson P. Determinants of Entrepreneurial Intentions, Paper Presented at the RENTLX Conference (1995) pp 23-24

[2] Rauch A, Frese M. Psychological Approaches to Entrepreneurial Success: A General Model and an Overview of Findings, International Review of Industrial and Organizational Psychology (2000) pp 101-142

[3] Hitt MA, Ireland RD, Camp SM. Strategic Entrepreneurship: Entrepreneurial Strategies for Wealth Creation, Strategic Management Journal (2001) pp 479-491

[4] Ardichvili A Cardozo RN, Ray S. A Theory of Entrepreneurial Opportunity Identification and Development. Journal of Business Venturing (2003) pp 105-123

[5] Begley TM, Boyd DP. Psychological Characteristics Associated with Performance in Entrepreneurial Firms and Smaller Businesses. Journal of Business Venturing (2007) pp 79-93

[6] Markley D. Entrepreneurial Support Organizations. Center for Rural Entrepreneurship Monograph (2013) pp 1-4

[7] Low MB, MacMillanI C. Entrepreneurship: Past Research and Future Challenges. Journal of Management (2008) pp 139-161

[8] Shane B, Venkataraman. The Promise of Entrepreneurship as a Field of Research. Academy of Management Review (2010) pp 217-226

[9] Seibert SE, Kraimer, ML, Liden RC. A Social Capital Theory of Career Success. Academy of Management Journal (2011) pp 219-237 